\title{
Life in the Palaeozoic: an overview of land and sea ecosystems
}

\author{
HUMBERTO G. FERRÓN \& CARLOS MARTínEZ-PÉREZ
}

\author{
The Palaeozoic Era: an overview of land and sea ecosystems
}

The Palaeozoic Era, lasting from 541-252 million years ago, was a time of dramatic geographical, climatic, and evolutionary changes. During this Era, life experienced a tremendous transformation and many critical macroevolutionary events took place, including important biotic radiations and diversifications, and three of the five major mass extinctions on the Earth history (Raup \& Sepkoski 1982). The advent and diversification of most modern metazoan phyla occurred during the Cambrian and Ordovician periods, in the so-called Cambrian Explosion and Great Ordovician Biodiversification Event (GOBE) (Servais et al. 2010). During the Ordovician, tectonic movements lead to a global cooling that culminated in the Hirnantian glaciation and the first of the five major extinction crisis (Sheehan 2001). Shortly after, life recovered and land was colonized during the Silurian by plants and different groups of arthropods, establishing the first forests during the Devonian (Behrensmeyer 1992). The land transformation caused drastic terrestrial changes with the development of new habitats that allowed the appearance of freshwater ecosystems with increasingly complex ecological interactions (Scheckler 2006). In this context, the colonization of terrestrial environments took place by the first tetrapods, constituting one of the most important events in the evolutionary history of vertebrates (Niedźwiedzki et al. 2010). At the same time, diversity-saturation in marine benthic habitats and the high abundance of planktonic food lead to the occupation of the water column by many animal groups, an event known under the name of "the Devonian Nekton Revolution" (Klug et al. 2009). At the end of the Devonian Period, a second major extinction episode occurred at the Frasnian-Famennian boundary in both marine and terrestrial ecosystems (Barash 2016). Life flourished again during the Carboniferous with unprecedented levels of atmospheric oxygen, which lead to the evolution of unusual gigantic body sizes in several non-related groups of animals (Harrison et al. 2010). The end of the Palaeozoic Era was marked by the greatest extinction of the Phanerozoic Eon, the Permo-Triassic extinction, which entailed the loss of as much as 95\% of all species on Earth (Benton \& Twitchett 2003).

All these key events have determined in a large extent the later evolutionary history of life and, as consequence, their study is critical for achieving a proper understanding of the Mesozoic and Cenozoic eras, as well as explaining the current biological, taxonomical and ecological diversity. Fossil Record provides a unique opportunity in this sense, and therefore its understanding is one of the primary goals of palaeontology. This requires undoubtedly a multidisciplinary approach, including systematic, palaeogeographic, palaeoecologic and evolutionary studies that, in a lower scale, are represented in the special volume herein published, grouping some of the contributions presented at the special workshop 'Life in Palaeozoic: an overview of land and sea ecosystems' during the $1^{\text {st }}$ International Meeting of Early-stage Researchers in Palaeontology.

\section{$1^{\text {st }}$ International Meeting of Early-stage Researchers in Palaeontology (IMERP)}

The " $1{ }^{\text {st }}$ International Meeting of Early-stage Researchers in Palaeontology/XIV Encuentro de Jóvenes Investigadores en Paleontología" ( $1^{\text {st }}$ IMERP/XIV EJIP) was an event focused on promoting scientific vocation among young students in palaeontology at different stages of their formation. This meeting has been organized during the last 13 years under the name of "Encuentro de Jóvenes Investigadores en Paleontología" (EJIP) as an important event in Spain, becoming the first essential step in the formation of new Spanish and Portuguese palaeontologists. However, in the last meeting, in an attempt to broaden the scope and impact of the conference, the Organizing Committee decided to internationalize it under the name of the $1^{\text {st }}$ International Meeting of Early-stage Researchers in Palaeontology.

For years, this event has stimulated the exchange of ideas, views and scientific methods, with the aim of promoting the career development of new generations of palaeontologists. Hence the $1^{\text {st }}$ IMERP/XIV EJIP aimed to be a forum for discussion between young researchers and professionals in palaeontology from both academic and private world, promoting entrepreneurship among university students with the aim of helping to develop their scientific careers. 
The congress, organised by the University of Valencia, was held in the small locality of Alpuente (Valencia, Spain) on April 2016 and hosted more than 160 researchers on palaeontology from 16 different nationalities of 4 continents (Europe, America, Asia and Oceania). Due of the great number of contributions, the $1^{\text {st }}$ IMERP/XIV EJIP was divided in five different workshops: 'Life in Palaeozoic: an overview of land and sea ecosystems', 'Palaeobiodiversity and evolution in the Mesozoic world', 'Tertiary ecosystems: evolution and palaeoenvironments', 'New insights on Quaternary ecosystems' and 'General Palaeontology'. The present volume represent a small sample of the 23 contributions, 12 oral communications and 11 posters, presented at the "Life in Palaeozoic: an overview of land and sea ecosystems" workshop. Those contributions included works dealing from the Cambrian to the Permian and with a wide range of topics and groups: conodonts, brachipodos, trilobites, echinoderms, vertebrates, diversity analyses, bioevents, palaeoecology, ichnites, etc. This volume, somehow, summarizes the excellent results achieved during the conference. In particular, the five contributions that constitute this volume emphasize the importance of the biotic events that took place during the Palaeozoic times, resulting in important contributions to better understanding the consequences of the Great Ordovician Biodiversification Event (GOBE) and different Devonian Bioevents.

\section{Special issue contributions}

As commented above, this volume is the compilation of the extended versions of some of the works presented in the workshop 'Life in Palaeozoic: an overview of land and sea ecosystems', within the frame of the ' 1 st International Meeting of Early stage Researchers in Palaeontology/XIV Encuentro de Jóvenes Investigadores en Paleontología'. The five works included in this special volume of Bulletin of Geosciences are focused in two time intervals, Ordovician and Devonian, dealing with different taxonomical groups (conodonts, echinoderms, trilobites, brachiopods, molluscs and vertebrates) which are studied from a systematic, biostratigraphic and ecological points of view.

The works comprising this volume include, on one hand, those contributions of Colmenar et al. (2017) and Pereira et al. (2017) focused on the study of the Ordovician faunas (mainly brachiopods and trilobites) from Portugal, Spain, Czech Republic and Morroco; and secondly the contributions of Lu et al. (2017), Chevrinais et al. (2017) and Klug et al. (2017), all of them focused on the Devonian Period including two main approaches, conodont biostratigraphy (Lu et al. 2017), and palaeoecology (Chevrinais et al. 2017, Klug et al. 2017).

The contribution of Colmenar et al. (2017) concerns the description of the benthic association (bryozoans, echinoderms, brachiopods and trilobites) of the Ferradosa Formation (Central Portugal) (upper Katian, Upper Ordovician) with remarks on its significance for the redefinition and subdivision of the Kralodvorian Regional Stage. This contribution is an important addition to the knowledge of the Portuguese Late Ordovician benthic marine communities, providing crucial new data to constrain the biostratigraphy of the Ferradosa Formation and the palaeogeographical setting of this region at that time. The second Ordovician contribution, is that presented by Pereira et al. (2017) focused on the illaenid trilobites Vysocania and Octillaenus from the Upper Ordovician of the Czech Republic, Portugal, Spain and Morocco, with the revision of the criteria used for the definition of these genera, the relationships between them and its geographical distribution. It is important to highlight that this study has allowed the description of two new species $V$. moraveci sp. nov. and O. marocanus sp. nov.

The second block of contributions is focused on the Devonian. Chevrinais et al. (2017) approached the early establishment of vertebrate trophic interactions in two Middle to Late Devonian fish assemblages with exceptional fossilization: the Escuminac assemblage at Miguasha, eastern Canada, and the Lode assemblage at Straupe, Latvia. As stated by Chevrinais et al. (2017), both localities are representatives of Middle to Late Devonian aquatic vertebrate assemblages in terms of taxonomic richness, phylogenetic and palaeoenvironment diversity. The most interesting conclusion of this work is that the Devonian vertebrate communities were organized in multiple trophic levels, comparable to those of recent aquatic ecosystems, showing a consistency of aquatic food web structure across geological time, and indicating that size-based feeding interactions were established early in vertebrate history. This interesting palaeoecological paper, is completed by the study of Klug et al. (2017) describing a new major macroecological event during the Silurian-Devonian times, the so-called Siluro-Devonian Jaw Armament in relationship with the Palaeozoic Plankton Revolution and the Devonian Nekton Revolution. Klug et al. (2017) discuss the evolutionary advancement in oral equipment, i.e. the Palaeozoic evolution of mouthparts and jaws in a macroecological context, standing out that during the Siluro-Devonian important innovations in the evolution of oral structures occurred.

Finally, the Devonian contributions are completed with the manuscript of Lu et al. (2017) focused on the study of the conodont fauna of the Nalai Section (Guangxi) in South China. The systematic and biostratigraphic work presented by the authors show a rich assemblage of conodonts with the presence of numerous species of the genera Polygnathus and 


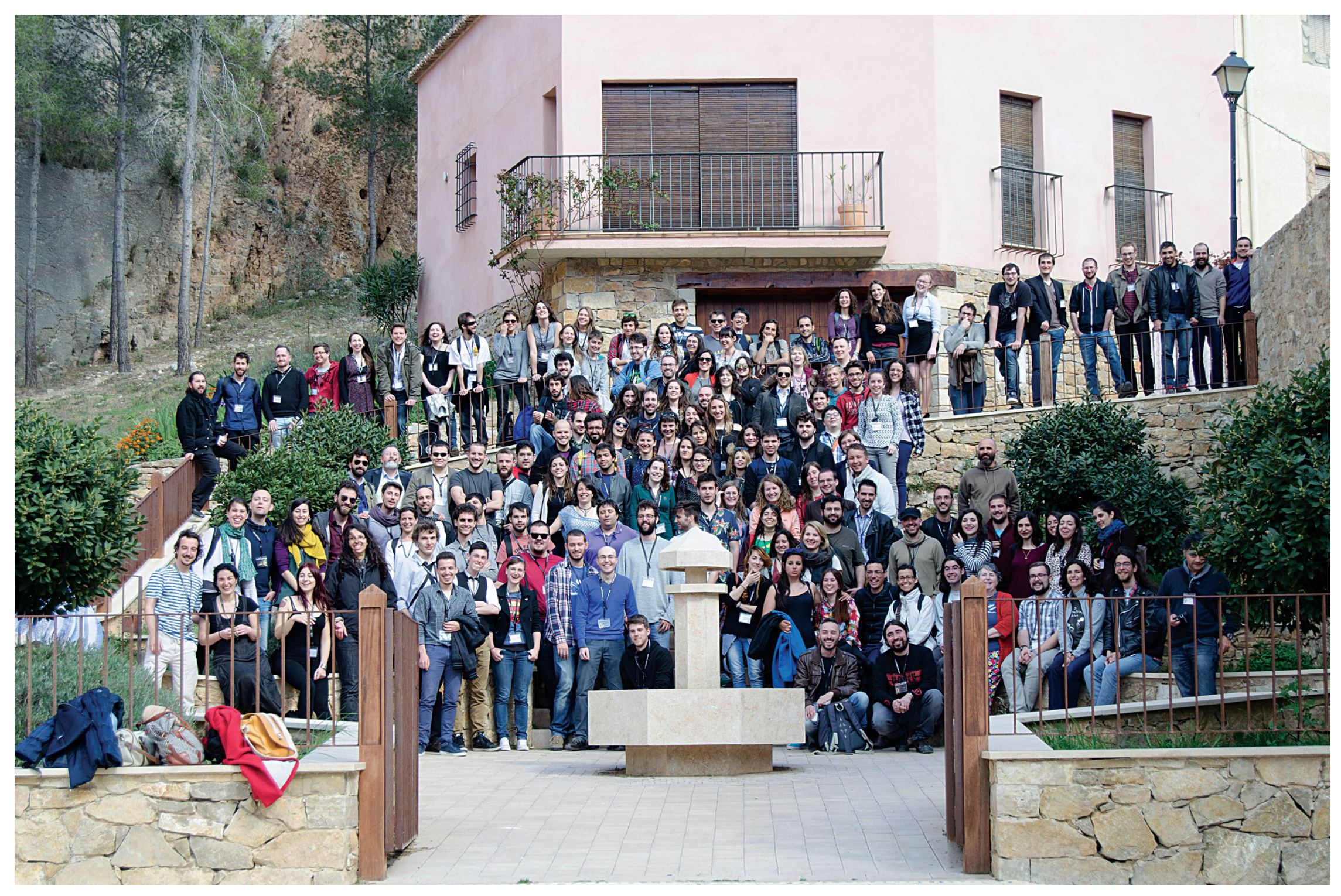

Figure 1. Participants of the $1^{\text {st }}$ International Meeting of Early-stage Researchers in Palaeontology /XIV Encuentro de Jóvenes Investigadores en Paleontología, Alpuente (Valencia Province), Spain, during 13-16 April 2016. 
Bipennatus, allowing, for the first time, the assignation to the serotinus Zone (Emsian, Lower Devonian) the Zdimir bed of the Beiliu Formation. The new data found in the Nalai Section is in addition correlated with other seven China sections, suggesting that the Zdimir beds in South China belong to the serotinus Zone and to the partitus Zone. The study is an important contribution for better understanding of the poorly studied Lower Devonian conodont biostratigraphy of South China.

\section{Acknowledgements}

We would like to thank all the people who participated and organized the $1^{\text {st }}$ IMERP/XIV EJIP. We would like to give special thanks to the people of the towns of Alpuente, Titaguas, La Yesa and the Natural Sciences Museum of Valencia, which hosted the event. We also thank our colleagues of the Organizing Committee from the other workshops, and the authors which contributions have made this volume possible. Finally, we would like to thank to the editors of the Bulletin of Geosciences Jiří Frýda, Šárka Sedláčková and Zuzana Tasáryová for their work handling with the review process of the submitted manuscripts and for supporting us in this modest but important project.

\section{References}

BARASH, M.S. 2016. Causes of the great mass extinction of marine organisms in the Late Devonian. Oceanology 56, 863-875. DOI 10.1134/S0001437016050015

BEHRENSMEYER, A.K. 1992. Terrestrial ecosystems through time: evolutionary paleoecology of terrestrial plants and animals. 588 pp. University of Chicago Press, London.

Benton, M.J. \& Twitchett, R.J. 2003. How to kill (almost) all life: the end-Permian extinction event. Trends in Ecology \& Evolution 18, 358-365. DOI 10.1016/S0169-5347(03)00093-4

Chevrinais, M., JACQuet, C. \& Cloutier, R. 2017. Early establishment of vertebrate trophic interactions: Food web structure in Middle to Late Devonian fish assemblages with exceptional fossilization. Bulletin of Geosciences 92(4), 491-510.

DOI 10.3140/bull.geosci.1651

Colmenar, J., Pereira, S., Pires, M., Silva, C.M., SÁ, A.A. \& Young, Y.P. 2017. A Kralodvorian (upper Katian, Upper Ordovician) benthic association from the Ferradosa Formation (Central Portugal) and its significance for the redefinition and subdivision of the Kralodvorian Stage. Bulletin of Geosciences 92(4), 443-464. DOI 10.3140/bull.geosci.1643

Harrison, J.F., Kaiser, A. \& VAndenBrooks, J.M. 2010. Atmospheric oxygen level and the evolution of insect body size. Proceedings of the Royal Society of London B: Biological Sciences 277, 1937-1946. DOI 10.1098/rspb.2010.0001

Klug, C. Frey, L. Pohle, A., De Baets, K. \& Korn, D. 2017. Palaeozoic Evolution of Animal Mouthparts. Bulletin of Geosciences 92(4), 511-524. DOI 10.3140/bull.geosci.1648

Klug, C., Kröger, B., Kiessling, W., Mullins, G.L., Servais, T., FrýdA, J., Korn, D. \& Turner, S. 2010. The Devonian nekton revolution. Lethaia 43, 465-477. DOI 10.1111/j.1502-3931.2009.00206.x

Lu, J., Valenzuela-Ríos, J.I., Chen, X. \& Liao, C.J. 2017. Conodont biostratigraphy of the Nalai section (Guangxi) and new data on the age of the Zdimir beds in South China. Bulletin of Geosciences 92(4), 525-544. DOI 10.3140/bull.geosci.1660

Niedźwiedzki, G., Szrek, P., Narkiewicz, K., Narkiewicz, M. \& Ahlberg, P.E. 2010. Tetrapod trackways from the early Middle Devonian period of Poland. Nature 463, 43-48. DOI 10.1038/nature08623

Pereira, S., Silva, C.M., SÁ, A.A., Marques Guedes, A., Budil, P., Laibl, L. \& Rábano, I. 2017. The Illaenid trilobites Vysocania and Octillaenus from the Upper Ordovician of the Czech Republic, Portugal, Spain and Morocco. Bulletin of Geosciences 92(4), 465-490. DOI 10.3140/bull.geosci.1642

RAUP, D.M. \& SEPKOSKI, J.J. 1982. Mass extinctions in the marine fossil record. Science 215, 1501-1503. DOI 10.1126/science.215.4539.1501

SCHECKLER, S.E. 2006. Devonian forest expansion increased land-based trophic capacity and food web connections. Geological Society of America Abstract Programs 38, 340.

Servais, T., Owen, A.W., Harper, D.A., Kröger, B. \& Munnecke, A. 2010. The great ordovician biodiversification event (GOBE): the palaeoecological dimension. Palaeogeography, Palaeoclimatology, Palaeoecology 294, 99-119. DOI 10.1016/j.palaeo.2010.05.031

SHeEHAn, P.M. 2001. The late Ordovician mass extinction. Annual Review of Earth and Planetary Sciences 29, 331-364. DOI 10.1146/annurev.earth.29.1.331 